\title{
A CONSTITUTION FOR KNAVES CROWDS OUT CIVIC VIRTUES
}

\author{
Bruno Frey
}

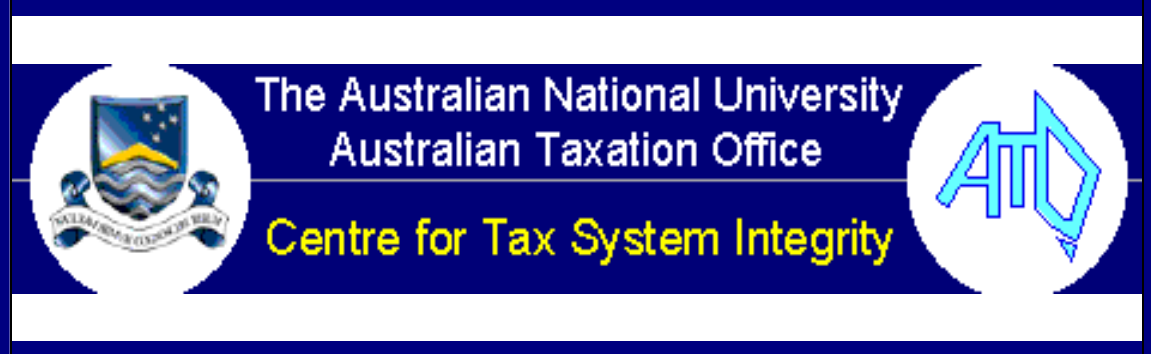

WORKING PAPER No 31

June 2002 


\title{
A CONSTITUTION FOR KNAVES CROWDS OUT CIVIC VIRTUES
}

\author{
Bruno Frey
}

\author{
SERIES' EDITOR \\ Karen Byng
}

Centre for Tax System Integrity

Research School of Social Sciences

Australian National University

Canberra, ACT, 0200

ISBN 0642768307

ISSN 1444-8211

\section{WORKING PAPER No 31}

June 2002 
(C) Centre for Tax System Integrity, Research School of Social Sciences, Australian National University 2002

(C) Commonwealth of Australia 2002

National Library of Australia

Cataloguing-in-Publication data:

Frey, Bruno S., 1941 -

A constitution for knaves crowds out civic virtues.

Bibliography.

ISBN 0642768307.

1. Constitutional law - Australia - Citizen participation.

I. Centre for Tax System Integrity. II. Title. (Series :

Working paper (Centre for Tax System Integrity) ; no. 31).

342.9402

If you would like to make any comments on this working paper please contact the author directly within 90 days of publication.

\section{Disclaimer}

This article has been written as part of a series of publications issued from the Centre for Tax System Integrity. The views contained in this article are representative of the author only. The publishing of this article does not constitute an endorsement of or any other expression of opinion by the Australian National University or the Commissioner of Taxation of the author's opinion. The Australian National University and the Commissioner of Taxation do not accept any loss, damage or injury howsoever arising that may result from this article. This article does not constitute a public or private ruling within the meaning of the Taxation Administration Act 1953, nor is it an advance opinion of the Commissioner of Taxation. 


\section{THE CENTRE FOR TAX SYSTEM INTEGRITY WORKING PAPERS}

The Centre for Tax System Integrity (CTSI) is a specialised research unit set up as a partnership between the Australian National University (ANU) and the Australian Taxation Office (Tax Office) to extend our understanding of how and why cooperation and contestation occur within the tax system.

This series of working papers is designed to bring the research of the Centre for Tax System Integrity to as wide an audience as possible and to promote discussion among researchers, academics and practitioners both nationally and internationally on taxation compliance.

The working papers are selected with three criteria in mind: (1) to share knowledge, experience and preliminary findings from research projects; (2) to provide an outlet for policy focused research and discussion papers; and (3) to give ready access to previews of papers destined for publication in academic journals, edited collections, or research monographs.

Series' Editor:

Karen Byng 


\begin{abstract}
When discussing constitutional design, economists concentrate on the propensity of individuals to free ride. Preventing opportunistic behaviour by knaves has costs by crowding out civic virtue. Another view emphasises active citizen participation in order to bolster civic virtue. A viable constitution must therefore be strict enough to deter exploitative behaviour. At the same time, the constitution should fundamentally convey trust towards its citizens and politicians. Distrusting public laws risk destroying the positive attitude of citizens and politicians towards the state. Civic virtue can be maintained and fostered by direct citizen participation via popular referenda and initiatives.
\end{abstract}




\section{A constitution for knaves crowds out civic virtues ${ }^{1}$}

Bruno S. Frey ${ }^{2}$

Human beings act as knaves, if given the opportunity. A constitution should therefore be designed to limit the extent of exploitative behaviour. This view has been advanced by Brennan and Buchanan (1983), and forms the basis of constitutional economics.

Brennan and Buchanan offer two distinct propositions in their paper: (i) People are knaves if not constrained; (ii) A realistic model of (average) human behaviour is not a reasonable basis for normative institutional design because the harm caused by deviations away from the ideal is disproportionally large (convexity assumption). Rather, the worst-case scenario must be considered and society's laws must be so strict that they prevent such malevolent behaviour.

This vision has not gone unchallenged. ${ }^{3}$ This negative view of human beings is rejected by many, and others even reverse the problem: 'What most needs explanation ... is not why some people are criminals but why most are not' (Wilson, 1993, p. 24). Many authors (for example, Reich, 1988; Mansbridge, 1994) point out that public spiritedness exists in many polities. A number of influential books (for example, Etzioni, 1988; Wilson, 1993; Putnam, 1993; Fukuyama, 1995) show how moral obligations and trust in society shape the relationship between citizens and the state in a positive way ${ }^{4}$. These authors imply that, in many societies, civic virtue can be counted on and should be actively fostered. According to their view, a constitution should be designed to increase deliberation between the government and its citizens in order to overcome narrowly defined self-interest and to raise civic virtues. The basic (American) constitutional structures and many individual rights indeed serve this purpose (Sunstein, 1990).

\footnotetext{
${ }^{1}$ Economic Journal 1997 Volume 107 (July) 1043-1053.

${ }^{2}$ University of Zurich, Switzerland.

${ }^{3}$ It should be made clear that Brennan and Buchanan are well aware of, and even stress, the role of moral principles; they explicitly and repeatedly refer to moral considerations as constraining individuals' behaviour in the political context in their 1983 article. The same holds for Adam Smith who is not solely the great champions of self-interest but he spent much of his life exploring the role of moral sentiments, explicitly including public spirit, to make the world a better place (see Sen, 1995, p. 24). The essential point in our context is, however, that neither Buchanan and Brennan, nor Smith take into account the causal effect of the constitution on citizens' morale.

${ }^{4}$ This literature looks, however, at trust (or similar concepts) in government by the citizens while this paper mainly looks at trust in citizens by the government (constitution).
} 
The purpose of this paper is not to take issue with the two Brennan-Buchanan propositions as such, but to draw attention to a crucial aspect disregarded by them: A constitution designed for knaves, or even for purely self-interested citizens, tends to crowd out civic virtues. As a result, the citizens exploit all legal opportunities to the fullest and the constitution is less observed. The effort to constitutionally constrain citizens may thus lead to a perverse result. Although a constitution, and more generally public laws and regulations, must check against knaves and prevent the exploitation of the citizenry by free riders and by professional politicians, it should also support civic virtues. The general spirit of the law, including specific rules, should acknowledge the citizens' basic goodwill. The establishment of a trusting constitution does not automatically produce high civic virtues. This is only the case if the constitution is considered to be fair and productive, and hence is widely accepted. An important prerequisite for a trusting constitution is that it gives citizens extensive participation rights.

Crowding-out civic virtue, or more generally, intrinsic motivation echoes the well-known concern by Titmuss (1970) who claims that an inadequate public policy (in his case material rewards) destroys the moral incentives to donate voluntarily. Our knowledge of the conditions under which civic virtues and other moral motivations are undermined has progressed considerably since then. There now exists a well-defined crowding theory derived from social psychology and applied to economics which is much more differentiated than Titmuss' hunch. In particular, external intervention does not always crowd out intrinsic motivation. There are conditions under which it fosters intrinsic motivation (crowding-in). This theory is supported by much empirical evidence from laboratory experiments as well as from real life observations.

Section I expounds the crowding theory and the related spill-over effect of intrinsic motivation. Section II presents the respective empirical evidence. Section III applies the concept to the constitution and public rules in general, discussing the relevant conditions and drawing the consequences for legal design. Empirical evidence supporting the effect of the type of legal structure on civic virtues, in particular on tax morale, is presented in section IV. Concluding remarks are offered in section V. 


\section{Crowding theory}

Social psychologists have analysed and empirically measured the 'hidden cost of reward' (Lepper \& Greene, 1978; Deci \& Ryan, 1985) which appear when an external intervention (a reward) reduces individuals' intrinsic incentives to act. People are intrinsically motivated when they undertake an activity for its own sake. The hidden cost of reward has been observed, for instance, in asylums where paying the patients to perform certain tasks (such as making the bed or cleaning their room) undermines their motivation to complete them when they are not paid. An everyday example would be an invitation to a friend's home for dinner. Nobody would pay him for the effort because this would destroy his intrinsic motivation (his friendship).

Two psychological processes account for the hidden cost of reward:

(i) When individuals perceive the external intervention to be 'controlling' in the sense of reducing the extent to which they can determine actions by themselves, intrinsic motivation is substituted by extrinsic control. The locus of control shifts from the inside to the outside of the person affected. Individuals who are forced to behave in a specific way by outside intervention, would feel 'overjustified' if they maintained their intrinsic motivation. They rationally reduce the motivational factor under their control, that is intrinsic motivation.

(ii) An intervention from the outside undermines the actor's intrinsic motivation if it carries the notion that the actor's intrinsic motivation is not acknowledged. The person affected feels that his or her competence is not appreciated which leads to an impaired self-esteem, resulting in a reduced intrinsic motivation.

Based on these psychological processes, the hidden cost of reward can be generalized in two respects:

(a) All outside interventions can affect intrinsic motivation: in addition to rewards the same effect can come about by external regulations (commands);

(b) External interventions crowd-out intrinsic motivation if they are perceived to be controlling and they crowd-in intrinsic motivation if they are perceived to be supporting. 
Psychological crowding theory only relates to the effect on motivation (in which psychologists are particularly interested) but not on behaviour. It is necessary to simultaneously take into account the disciplining or (generalized) relative price effect on behaviour normally considered in economics. This is best done in a principal-agent setting.

A (representative) agent adjusts his or her performance $(\mathrm{P})$ considering the benefits $(\mathrm{B})$ and the cost $(\mathrm{C})$ induced. Moreover, benefits and costs are also influenced by the principal's external intervention $(\mathrm{E})$, yielding the following two equations:

$$
\begin{aligned}
& B=B(P, E) \\
& C=C(P, E)
\end{aligned}
$$

Both benefits and costs increase in performance, that is, $\frac{\partial B}{\partial P} \equiv B_{P}>0$ and $\frac{\partial C}{\partial P} \equiv C_{P}>0$. In addition, higher performance exhibits diminishing marginal returns $\left(\mathrm{B}_{\mathrm{PP}}<0\right)$ and has increasing marginal cost $\left(\mathrm{C}_{\mathrm{PP}}>0\right)$.

A rational agent chooses that level of performance $\left(\mathrm{P}^{*}\right)$ that maximizes net benefits $(\mathrm{B}-\mathrm{C})$ which yields the first-order condition

$$
\mathrm{B}_{\mathrm{P}}=\mathrm{C}_{\mathrm{P}}
$$

Differentiating this utility maximizing condition with respect to E shows how the agent's optimal performance $\left(\mathrm{P}^{*}\right)$ is affected when the principal changes the extent of external intervention

$$
\begin{aligned}
& \mathrm{B}_{\mathrm{PE}}+\mathrm{B}_{\mathrm{PP}} \frac{\mathrm{dP} *}{\mathrm{dE}}=\mathrm{C}_{\mathrm{PE}}+\mathrm{C}_{\mathrm{PP}} \frac{\mathrm{dP} *}{\mathrm{dE}}, \text { or } \\
& \frac{\mathrm{dP}^{*}}{\mathrm{dE}}=\frac{\mathrm{B}_{\mathrm{PE}}-\mathrm{C}_{\mathrm{PE}}}{\mathrm{C}_{\mathrm{PP}}-\mathrm{B}_{\mathrm{PP}}} \lesseqgtr 0 .
\end{aligned}
$$

Following standard principal-agent theory, external intervention raises performance by imposing higher marginal cost on shirking or, equivalently, by lowering the marginal cost 
of performing, $\mathrm{C}_{\mathrm{PE}}<0$. This is the relative price effect of an external intervention. As the crowding effect is neglected, that is, a change in external intervention does not affect the marginal utility of performing $\left(\mathrm{B}_{\mathrm{PE}}=0\right)$, the orthodox economic theory predicts that external intervention always raises performance $(\mathrm{dP} * / \mathrm{dE}>0)$. This positive effect is strengthened if the external intervention bolsters intrinsic motivation (crowding-in effect, $\left.\mathrm{B}_{\mathrm{PE}}>0\right)$. On the other hand, the crowding-out effect $\left(\mathrm{B}_{\mathrm{PE}}<0\right)$ and the disciplining effect $\left(\mathrm{C}_{\mathrm{PE}}<0\right)$ of an external intervention work in opposite directions, so that the outcome $\mathrm{dP} * / \mathrm{dE}$ depends on the relative size of $\mathrm{C}_{\mathrm{PE}}$ and $\mathrm{B}_{\mathrm{PE}}$.

This paper argues, and empirically shows, that the institutional design also systematically affects the factor $\mathrm{B}_{\mathrm{PE}}$ : a constitution mistrusting its citizens under identifiable constitutions leads to a negative $\mathrm{B}_{\mathrm{PE}}$, while a constitution acknowledging and supporting its citizens' civic virtue has a positive $\mathrm{B}_{\mathrm{PE}}$.

A number of empirically observable conditions for the sign and size of the crowding effect have been identified in the literature (Lane, 1991; Frey, 1992). In the context of constitutional design, two conditions proved to be the most important:

(1) The individual's institutional participation possibilities. When a person is simply subjected to a decision, she perceives the interference to be controlling, and her intrinsic motivation for the respective activity is crowded out (condition 1a). If, on the other hand, a person is able to take part in a decision, her self-esteem is supported, and her intrinsic motivation is crowded in (condition $1 b$ ).

(2) The closer the interaction between the person or institution administering the intervention and the person being subjected to it, the more negative is the crowding effect $\left(\mathrm{B}_{\mathrm{PE}}\right)$. In particular, the stronger the communication between the two sides, the more likely intrinsic motivation is crowded out.

External interventions may moreover have an indirect damaging effect on intrinsic motivation. The crowding out effect may spread to further areas, even into those where the 
external intervention has not been applied. There may thus be an indirect 'motivational spill-over effect' which has to be added to the direct crowding-out effect. The fact that changes in intrinsic motivations (in the broadest sense) may be linked across areas has been known as the 'spread effect' in psychology and has also been noted by various economists, though they have not related it to crowding-out (for example, Sugden, 1989, p. 93; Williamson, 1992, p. 256). In the United States, for instance, strong correlations have been identified between changes in voter participation, charitable contributions and other forms of social cooperation attributing to declines in intrinsic motivation (civic norms) in a multiple regression analysis (Knack, 1992).

\section{Crowding-out: empirical evidence}

Crowding theory is supported by a large number of experiments undertaken by social psychologists (see Deci \& Ryan, 1985; Lane, 1991). Empirical analyses of real life behaviour also present evidence in favour of the crowding-out effect. A study by Barkema (1995) looks at 116 managers in medium-sized Dutch firms where the intensity of the personal supervision of lower level managers by supervisors varies. According to condition (2), the closer this personal interaction is, the more pronounced is the crowding-out effect. The more personalized the supervision, the more (statistically significantly) negative are the econometrically estimated parameters capturing the effect of external intervention on work ( $\mathrm{B}_{\mathrm{PE}}$ in eq. 4), which is consistent with the above hypotheses.

An important real life issue where crowding theory is relevant, is the resistance to the siting of locally unwanted projects (the so-called 'Not In My Backyard' or NIMBYsyndrome). Many economists have suggested monetary compensation to overcome the siting problem. Crowding theory suggests that when the citizens are involved in the decision process (condition 1b), the compensation offer reduces civic virtue and subsequently the support for the noxious facility. This proposition was tested for the siting of a nuclear waste repository in Switzerland (see, more fully, Frey, Oberholzer-Gee \& Eichenberger, 1996). A survey based on 305 personal interviews was conducted in the communities chosen as possible sites by the government. More than half the respondents $(50.8 \%)$ agreed to have the repository built in their community though a large majority of 
the respondents $(80 \%)$ were well aware of the risks involved. To test the effect of a monetary reward offered, we repeated the same question, but added that the Swiss government had decided to compensate all residents of the host community. The amount offered varied between SFr. 2500 per individual and year $(\mathrm{N}=117)$, to SFr. $5000(\mathrm{~N}=$ 102), and SFr. $7500(\mathrm{~N}=86)$ which is substantial in view of a median household income of our respondents of SFr. 63000 per year.

While $50.8 \%$ of the respondents agreed to accept the nuclear waste repository without compensation, acceptance drops to $24.6 \%$ when compensation is offered..$^{5}$ This (surprising) result is consistent with the hypotheses about crowding out intrinsic motivation also found in other research. Thus, increased tax rebates did not elicit an increased willingness to accept a nuclear waste facility in Nevada, and the suspicion that the rebates offered were simply too small is explicitly rejected (Kunreuther \& Easterling, 1990).

The motivational spill-over effect is also supported by real life evidence. In our study of the nuclear waste repository in Switzerland, it was found that compensating the citizens of the prospective host community (Wolfenschiessen) also reduced the civic virtue of individuals living in adjacent communities. As a result, a popular referendum of June 1995 in the communities surrounding Wolfenschiessen rejected the siting proposal because the citizens felt that their intrinsic motivation was not appreciated by the central government. Communities farther away from the planned site approved the proposal.

\section{Constitutional design}

Crowding theory helps to explain how constitutional and other legal rules affect the individual citizens. Civic virtue is bolstered if the public laws convey the notion that citizens are trusted. Such trust is reflected in extensive democratic participation possibilities (condition 1). Citizens are given the freedom to express themselves, to be heard by the politicians and public officials, and to carry out discussions with them. The basic notion enshrined in the constitution that citizens are on average, and in general,

\footnotetext{
${ }^{5}$ The size of the compensation has no statistically significant effect on acceptance.
} 
reasonable human beings thus generates a crowding-in effect of civic virtue. This implies, however, that interventions constraining citizens are mild because according to condition 2 , the crowding-out effect is strong in this case.

In contrast, a constitution that implies a fundamental distrust of its citizens and seeks to discipline them tends to crowd out civic virtue and undermines the support which citizens are prepared to exert towards the basic law. 'If people feel that they are taken advantage of, why should they not rip off the system in return?' (Elster, 1989, p. 180). This distrust towards the citizens manifests itself in various ways. Institutions of political participation are curtailed because the 'classe politique' feels that citizens are unable to take reasoned political decisions.

Another sign of distrust towards the citizens is also enshrined in a constitution where the government is given great power to intervene in the economy and society, and where little room is left to the individuals to act on their own. Controls by bureaucracy and police are then extensive, and no citizen is taken to be trustworthy. The burden of the proof to have acted correctly lies with the individual citizen while the public authority is considered to be correct a priori. Such a distrustful constitution undermines the citizens' civic virtue. They respond by taking full advantage of all opportunities and by breaking the constitution and its laws whenever they expect to do so at low cost, and the political system is characterized by high transaction costs and low productivity. A vicious cycle of progressively lower civic virtue and increasing distrust by the rulers may lead to general cynicism. Such a development has occurred in many communist countries and still exists in totalitarian systems. Citizens may be unwilling to cooperate with the state in many other ways, for example, by refusing to support projects in the national interest. Distrustful public laws also favour tax evasion, that is, citizens make an effort to minimize their tax burden by illegitimate or illegal action.

The mistrust embedded in the constitution has so far been interpreted to be directed against the citizens. The main thrust of the argument for a strict constitution as advanced by Brennan and Buchanan (1983) is, however, that (professional) politicians are to be mistrusted because they have an inherent tendency to abuse political power and to exploit 
the citizens. Following crowding theory, to imply in the constitution that politicians are crooks in any case is likely to undermine their civic virtue and to make them more dishonest. At the same time, 'bad' politicians can indeed impose great harm on others, while 'bad' citizens and politicians can do so much less. A constitution must thus reflect trust towards citizens and politicians in order to safeguard their civic virtue, and at the same time put limits on politicians in order to prevent them from exploiting the ordinary citizens. In so far as the ordinary citizens are given rights to reverse decisions taken (via referenda), and initiate laws opposed by the professional politicians (via initiatives), both goals can be achieved at the same time.

To generally and deeply mistrust the 'classe politique' as done in the work of Brennan and Buchanan, and enshrined in their constitutional proposals, comes at a price. In the case of politicians, it does not only consist of the direct crowding-out effect which transforms average human beings with an average level of civic virtue into politicians with a low sense of public spiritedness. It also consists of a selection effect which accentuates the crowding-out effect: Persons with particularly low civic virtue are especially attracted to a political career because they do not feel unjustly constrained by the constitutional rules. They feel perfectly at ease in an environment in which public spiritedness is absent. In contrast, persons with high civic virtue are confronted with an additional cost when they consider to enter the political sphere. The price of having politicians with low civic virtue consists of the higher cost of safeguards designed to prevent them from exploiting ordinary citizens. As it is impossible to completely control politicians in the public sphere, trust and high civic virtue is even more important in politics than elsewhere. Politicians acting as knaves are then subject to the social control by other politicians who are likely to be endowed with particularly good information to detect and counteract such behaviour.

Obviously, not all strict public laws lead to harmful consequences. It has already been said that an outside intervention may have a positive effect on intrinsic motivation if it is perceived to be supporting. In particular, laws that prevent free riding by others, and establish fairness and equity serve to maintain or even crowd-in civic virtue. One of the most damaging effects on individuals' willingness to obey the laws is the perception that others do not, or are not willing, to contribute their fair share, most importantly with 
respect to paying taxes. It has been shown, for example, that the propensity to evade taxes systematically increases with the perception of tax avoidance by other persons (for the empirical findings see, for example, Klasko, 1992, pp. 179-86). In experiments with prisoners' dilemma and similar problems, the extent of cooperation drastically declines when others were observed, and tolerated to be, 'suckers' (see for example, Brubaker, 1975 for evidence; and Taylor, 1987 on 'conditional cooperation').

\section{Testing the theory}

Attempts to measure the effect of different constitutional conditions on citizens' civic virtue are faced with obvious difficulties and uncertainties. Most promising is an indirect approach looking at revealed behaviour in equilibrium. It is applied here to capture tax morale, an important component of civic duty. As has been well established, tax paying behaviour cannot be explained in a satisfactory way without taking tax morale into account. Thus, based on the American Internal Revenue Service's Taxpayer Compliance Maintenance Program, Graetz, Reinganum and Wilde (1986) attribute the falling tax compliance in the United States to the erosion of tax morale (see also Slemrod, 1992).

The state of tax morale depends on the type of constitution. Switzerland presents a suitable test case because the various cantons have different degrees of political participation possibilities (see more fully, Pommerehne \& Frey, 1993). Following conditions 1 and 2 outlined above, it is hypothesized that the more extended political participation possibilities in the form of citizens' meetings, obligatory and optional referenda and initiatives are, and the broader the respective competencies are, the higher is tax morale and (ceteris paribus) tax compliance. On the basis of such characteristics, about one third of the 26 Swiss cantons are classified as pure direct democracies (D), another third as pure representative democracies (R), and the rest satisfies only some of these characteristics, and thus have an intermediate position. 
A cross section / time series (for the years 1965, 1970, 1978, that is, 78 observations) multiple regression explaining the part of income not declared $\mathrm{Y}_{\mathrm{nd}}{ }^{6}$, yields the following results $^{7}$ (t-values in parentheses):

$$
\begin{aligned}
& \mathrm{Y}_{\mathrm{nd}}=7.17-3.52 \mathrm{p}-2.42 \mathrm{f}+0.79 * \mathrm{t}-0.36 * \mathrm{~d}-2.72 \mathrm{Y}(\ln )+0.57 * * \mathrm{NY}-1.09 * \mathrm{~A}-7.70 * * \mathrm{D} \\
& (-1.98) \quad(-0.62)(2.10) \quad(-2.51) \quad(-0.30) \\
& \mathrm{R}^{2}(\operatorname{adj} .)=0.69 \text {, d.f. }=42, \mathrm{~F}=11.08 \\
& \mathrm{Y}_{\mathrm{nd}}=8.98-3.22 \mathrm{p}-2.32 \mathrm{f}+0.59 \mathrm{t}-0.42 * * \mathrm{~d}+1.03 \mathrm{Y}(\mathrm{ln})+0.60 * * \mathrm{NY}-0.82 \mathrm{~A}+4.02 * \mathrm{R} \\
& \begin{array}{lllll}
(-1.72) & (-0.36) & (1.70) & (-3.47) & (0.29)
\end{array} \\
& \mathrm{R}^{2} \text { (adj.) }=0.65 \text {, d.f. }=42, \mathrm{~F}=9.43 \\
& *, * * \text { indicate statistical significance at the } 95 \% \text { and } 99 \% \text { levels respectively }
\end{aligned}
$$

The variables are:

$$
\begin{aligned}
& Y_{n d}=\text { the part of income not declared } \\
& \mathrm{p}=\text { probability of detection (the number of individual income tax audits per } 1000 \text { tax } \\
& \text { payers); } \\
& \mathrm{f}=\text { penalty tax rate; } \\
& \mathrm{t}=\text { mean marginal tax rate; } \\
& \mathrm{d}=\text { income deduction possibilities; } \\
& \mathrm{Y}(\mathrm{ln})=\text { per capita income (in natural log.); } \\
& \mathrm{NY}=\text { non-wage income; } \\
& \mathrm{A}=\text { old-age taxpayers' share (reflecting experience in tax matters). }
\end{aligned}
$$

The coefficients of the variables indicating the type of democracy $(D, R)$ - the other variables are used to control for other influences ${ }^{8}$ - have the theoretically expected signs. In cantons with a high degree of direct political control (D), tax morale is (cet. par.) higher.

\footnotetext{
${ }^{6}$ As collected by the tax authorities and other sources, see Pommerehne and Frey (1993).

${ }^{7}$ Due to multicolinearity between $\mathrm{D}$ and $\mathrm{R}(\mathrm{r}=0.6)$ two separate equations including $\mathrm{D}$ and $\mathrm{R}$ have been estimated.

${ }^{8}$ It may be observed that while many coefficients are statistically highly significant and have the theoretically expected signs, the probability of detection (p) and the size of the fine (f) are not statistically significant at the conventional levels, that is, it cannot be presumed that deterrence works.
} 
The part of income concealed falls short of the mean of intermediate cantons by 7.7 percentage points. In absolute terms, the average amount of income concealed is about SFr. 1,600 (per taxpayer) less than the mean income concealed in all cantons. In contrast, in cantons with a low degree of direct political control (R), tax morale is (cet. par.) lower. The part of concealed income is four percentage points higher than the average income gap, and the mean income undeclared exceeds the mean of intermediate cantons by about SFr. 1,500. The estimation results are consistent with the hypothesis that, in equilibrium, greater democratic participation possibilities go with higher civic virtue as reflected in taxpayer behaviour (corresponding evidence for the United States is provided in Smith, 1992).

The empirical evidence collected for Switzerland suggests that there are at least two stable social equilibria: In one the citizens have high tax morale and are prepared to contribute to public funds, provided this process is reasonably efficient and fair ('quasi-voluntary compliance', Levi, 1988). The corresponding tax laws trust the citizens by allowing them to declare their own income and to make generalized deductions. The tax statements are in principle assumed to be correct. The overall tax administration and transaction costs are low. In the second type of tax equilibrium, citizens have low tax morale; they exploit the tax laws to the fullest, and cheat whenever they can. The tax administration is large and costly. The corresponding tax laws distrust citizens.

The two types of tax equilibria can be empirically associated with the general level of civic virtue and tax evasion in particular countries. A trusting tax system, a correspondingly high tax morale and relatively low tax evasion exists in Switzerland. Econometric research on taxation has indeed revealed that the citizens' willingness to pay taxes cannot reasonably be explained by an expected utility calculus based on the probability of detection and magnitude of fine. The implied risk aversion to account for observed behaviour would be unbelievably higher than anywhere else empirically observed. A distrusting tax system exists in countries such as the Federal Republic of Germany, France and Italy where tax morale is low and tax evasion is relatively high (Frey \& Weck-Hannemann, 1984).

The results of our econometric analysis have been indirectly supported by a larger set of other countries and also for civic virtue in general. An empirical study on an extensive 
sample of European as well as Central American countries clearly establishes a causation running from democracy to civic culture (Muller \& Seligson, 1994), that is, citizen participation rights help to promote public spirit. A cumulative body of research indicates that people's perceptions of how they are treated by government institutions strongly affect their willingness to cooperate with them. Citizens who consider the constitution and its laws, and the authorities acting on their basis to be fair and to treat them respectfully, tend to be more compliant than those with more negative perceptions of government (for empirical evidence see Tyler \& Kramer, 1996). The extensive use of adversary institutions for resolving public conflicts has been shown to negatively affect civic virtue, thereby appreciably raising transaction cost between the governments and citizens (Kelman, 1992).

\section{Concluding remarks}

The discussion of constitutional design is dominated by two extreme views. On the one hand, Brennan and Buchanan, their forerunners and followers in the tradition of constitutional economics concentrate on the perennial propensity of individuals to behave as opportunists and to free ride. But preventing knaves from exploiting the political system has not only advantages but also costs by crowding out civic virtue which is indispensable for an effective constitution and other public laws. The other extreme view of constitutional design emphasizes deliberation between politicians and citizens, and active citizen participation. The purpose is to support or crowd in civic virtue. A constitution is able to raise public spiritedness if it is widely accepted by the citizens to be fair and productive for all on average, that is, in the long run. It has been argued here, and has been supported by empirical evidence, that a successful way to maintain and enhance civic virtue are extensive constitutional rights of direct citizen participation via popular referenda and initiatives. But such a constitution runs a greater risk of knaves free riding and exploiting other citizens.

What is needed is a balanced constitution which escapes the dangers inherent in the two extreme conceptions. A viable constitution must be strict enough to effectively deter exploitative behaviour, not least because it undermines civic virtue if it becomes widespread. At the same time, care must be taken to design a system of laws 
fundamentally trusting citizens and politicians. Public laws designed for the worst possible behaviour as suggested by Brennan and Buchanan, run the risk of destroying the positive attitude of citizens and politicians towards their constitution which is necessary to maintain in efficiency, and is vital for its long-run survival. 


\section{REFERENCES}

Barkema, H. G. (1995). Do job executives work harder when they are monitored? Kyklos, $48,19-42$.

Brennan, G., \& Buchanan, J. M. (1983). Predictive power and the choice among regimes. Economic Journal, 93, 89-105.

Brubaker, E. R. (1975). Free ride, free revelation or golden rule? Journal of Law and Economics, 18, 147-161.

Deci, E. L., \& Ryan, R. M. (1985). Intrinsic Motivation and Self-Determination in Human Behaviour. New York: Plenum Press.

Elster, J. (1989). Solomonic Judgements: Studies in the Limitations of Rationality. Cambridge: Cambridge University Press.

Etzioni, A. (1988). The Moral Dimension. New York: Free Press.

Frey, B. S. (1992). Tertium datur: Pricing, regulating and intrinsic motivation. Kyklos, 45, 161-184.

Frey, B. S., \& Weck-Hannemann, H. (1984). The hidden economy as an unobserved variable. European Economic Review, 26, 33-53.

Frey, B. S., Oberholzer-Gee, F. \& Eichenberger, R. (1996). The old lady visits your backyard: A tale of morals and markets. Journal of Political Economy, 104, 1297-1313.

Fukuyama, F. (1995). Trust. New York: Free Press. 
Graetz, M., Reinganum, J. F., \& Wilde, L. L. (1986). The tax compliance game: toward an interactive theory of law enforcement. Journal of Law, Economics and Organization, 39, $1-32$.

Kelman, S. (1992). Adversary and cooperationist institutions for conflict resolution in public policymaking. Journal of Policy Analysis and Management, 11, 178-206.

Klasko, G. (1992). The Principle of Fairness and Political Obligation. Lanham MD: Rowman and Littlefield.

Knack, S. (1992). Civic norms, social sanctions, and voter turnout. Rationality and Society, 4, 133-156.

Kunreuther, H., \& Easterling, D. (1990). Are risk benefit tradeoffs possible in siting hazardous facilities? American Economic Review, 76, 295-299.

Lane, R. E. (1991). The Market Experience. Cambridge: Cambridge University Press.

Lepper, M. R., \& Greene, D. (Eds.). (1978) The Hidden Costs of Reward: New Perspectives on the Psychology of Human Motivation. Hillsdale, NY: Erlbaum.

Levi, M. (1988). Of Rule and Revenue. Berkeley: University of California Press.

Mansbridge, J. J. (1994). Public spirit in political systems. In H. J. Aaron, T. E. Mann \& T. Taylor (Eds.), Values and Public Policy (pp. 146-172) Washington: Brookings.

Muller, E. N., \& Seligson, M. A. (1994). Civic culture and democracy: The question of causal relationships. American Political Science Review, 88, 635-652.

Pommerehne, W. W., \& Frey, B. S. (1993). The effects of tax administration on tax morale. Unpublished manuscript, Department of Economics, University of the Saar. 
Putnam, R. D. (1993). Making Democracy Work. Princeton: Princeton University Press.

Reich, R. B. (Ed.). (1988) The Power of Public Ideas. Cambridge, Mass.: Ballinger.

Sen, A. K. (1995). Moral codes and economic success. In S. Brittan, \& A. Hamlin (Eds.), Market Capitalism and Moral Values (pp.23-24). Aldershot: Edgar Elgar.

Slemrod, J. (Ed.). (1992) Why People Pay Taxes. Tax Compliance and Enforcement. Ann Arbor: University of Michigan Press.

Sugden, R. (1989). Spontaneous order. Journal of Economic Perspectives, 3, 85-98.

Sunstein, C. R. (1990). Political self-interest in constitutional law. In J. J. Mansbridge (Ed.), Beyond Self-Interest (pp209-223). Chicago and London: Chicago University Press.

Taylor, M. (1987). The Possibility of Cooperation. Cambridge: Cambridge University Press.

Titmuss, R. M. (1970). The Gift Relationship. London: Allen and Unwin.

Tyler, T., \& Kramer, R. M. (Eds.). (1996). Trust in Organizations. Thousand Oaks: Sage.

Wilson, J. Q. (1993). The Moral Sense. New York: Free Press.

Williamson, O. E. (1992). Calculativeness, trust and economic organization. Organizational behavior and industrial relations. Working Paper OBIR-59, University of California at Berkeley. 


\section{THE CENTRE FOR TAX SYSTEM INTEGRITY WORKING PAPERS}

No. 1. Braithwaite, V. \& Reinhart, M. The Taxpayers' Charter: Does the Australian Taxation Office comply and who benefits? December 2000.

No. 2. Braithwaite, V. The Community Hopes, Fears and Actions Survey: Goals and Measures. March 2001.

No. 3. Braithwaite, V., Reinhart, M., Mearns, M. \& Graham, R. Preliminary findings from the Community Hopes, Fears and Actions Survey. April 2001.

No. 4. Mearns, M., \& Braithwaite, V. The Community Hopes, Fears and Actions Survey: Survey method, sample representativeness and data quality. April 2001.

No. 5. Sakurai, Y., \& Braithwaite, V. Taxpayers' perceptions of the ideal tax adviser: Playing safe or saving dollars? May 2001.

No. 6. Wenzel, M. The impact of outcome orientation and justice concerns on tax compliance: The role of taxpayers' identity. June 2001.

No. 7. Wenzel, M. Misperceptions of social norms about tax compliance (1): A prestudy. June 2001.

No. 8. Wenzel, M. Misperceptions of social norms about tax compliance (2): A field-experiment. June 2001.

No. 9. Taylor, N. Taxpayers who complain about paying tax: What differentiates those who complain from those who don't? June 2001.

No. 10. Wenzel, M. Principles of procedural fairness in reminder letters and awareness of entitlements: A prestudy. June 2001.

No. 11. Taylor, N. \& Wenzel, M. The effects of different letter styles on reported rental income and rental deductions: An experimental approach. July 2001.

No. 12. Williams, R. Prosecuting non-lodgers: To persuade or punish? July 2001.

No. 13. Braithwaite, V. Tensions between the citizen taxpaying role and compliance practices. Forthcoming.

No. 14. Taylor, N. Understanding taxpayer attitudes through understanding taxpayer identities. July 2001.

No. 15. Shover, N., Job, J. \& Carroll, A. Organisational capacity for responsive regulation. August 2001. 
No. 16. Tyler, T. R. Trust and law-abidingness: A proactive model of social regulation. August 2001.

No. 17. Genser, B. Corporate income taxation in the European Union: Current state and perspectives. August 2001.

No. 18. McBarnet, D. When compliance is not the solution but the problem: From changes in law to changes in attitude. August 2001.

No. 19. Schneider, F., Braithwaite, V. \& Reinhart, M. Individual behaviour in Australia's shadow economy: Facts, empirical findings and some mysteries. September 2001.

No. 20. Taylor, N. \& Wenzel, M. Comparing rental income and rental deductions for electronic versus paper lodgers: A follow-up investigation. November 2001.

No. 21. Braithwaite, J. Through the eyes of the advisers: A fresh look at tax compliance of high wealth individuals. September 2001.

No. 22. Braithwaite, J., Pittelkow, Y. \& Williams, R. Tax Compliance by the very wealthy: Red flags of risk. September 2001.

No. 23. Braithwaite, J. \& Williams, R. Meta risk management and tax system integrity. October 2001.

No. 24. Braithwaite, J. \& Wirth, A. Towards a framework for large business tax compliance. November 2001.

No. 25. Murphy, K. \& Sakurai, Y. Aggressive Tax Planning: Differentiating those playing the game from those who don't. October 2001.

No. 26. Morgan, S. \& Murphy, K. The 'Other Nation'? Understanding rural taxpayers' attitudes towards the Australian tax system. Forthcoming.

No. 27. Ahmed, E. \& Sakurai, Y. Small business individuals: What do we know and what do we need to know? Forthcoming.

No. 28. Hobson, K. Championing the compliance model: From common sense to common action? December 2001.

No. 29. Smart, M. The under thirty taxpayer: Different from the rest? Forthcoming.

No. 30. Job, J. \& Honaker, D. Short-term experience with responsive regulation in the Australian Taxation Office. May 2002.

No. 31. Frey, B. A constitution for knaves crowds out civic virtues. June 2002. 